\title{
Effect of urbanization on the avifauna in a tropical metropolitan area
}

\author{
Estaban Biamonte • Luis Sandoval • \\ Eduardo Chacón · Gilbert Barrantes
}

Received: 22 April 2010/Accepted: 24 November 2010/Published online: 5 December 2010

(C) Springer Science+Business Media B.V. 2010

\begin{abstract}
The rapid and unplanned expansion of urban areas is a common pattern in neotropical developing countries. Urbanization has eliminated or drastically altered large areas of natural habitats used by the rich neotropical avifauna. In our study area, in Costa Rica's Central Valley, urbanization increased $72 \%$ in 33 years with the consequent destruction, fragmentation, and isolation of forest tracts, shade plantations, and other semi-natural habitats used by a rich avifauna. We show that over the last 16 years 32 resident species of birds have disappeared from this area. Species with specialized habitat requirements or particular life history traits (e.g., altitudinal migrants) are disproportionately represented among those birds that have disappeared from the region. Another 34 latitudinal migrants have gone undetected as nearly all habitats these species used as a stopover site during the autumn migration have disappeared; many of these migrants were very abundant 16 years earlier. Relative abundance has also decreased for most resident and migratory species that remained or visited the area. If uncontrolled urban expansion
\end{abstract}

Electronic supplementary material The online version of this article (doi:10.1007/s10980-010-9564-0) contains supplementary material, which is available to authorized users.

E. Biamonte · L. Sandoval $(\bowtie) \cdot$ E. Chacón ·

G. Barrantes

Escuela de Biología, Ciudad Universitaria Rodrigo Facio,

San José, Costa Rica

e-mail: biosandoval@hotmail.com continues, we predict that the rate of extinction of the avifauna that originally inhabited this region would continue possibly increasing.

Keywords Birds - Conservation - Costa Rica · Fragmentation · Urban development

\section{Introduction}

Urbanization includes the expansion of urban areas into adjacent rural areas (Alig and Healy 1987; Joyce 2006). In the last three decades, this phenomenon has occurred at a rapid rate in developing countries mostly as a consequence of human population growth and population migration to urban centers (Pauchard et al. 2006). As urbanization increases, deforestation, habitat degradation, expansion of the agricultural frontier, and habitat fragmentation accelerates around urban nuclei (Harris 1984; Primack 1998; SánchezAzofeifa et al. 2001; Harvey et al. 2008), further isolating the few fragments of available habitat for resident and migrant birds (Melles et al. 2003). Isolation, fragmentation, and habitat degradation that result from urbanization expansion are directly related to population decline and local extirpation of many bird species worldwide (Bierregaard and Lovejoy 1988; Hughes et al. 1997; Manhães and Loures-Ribeiro 2005).

An observed phenomenon that occurs after destruction of large extensions of natural habitats is that those 
species that survive these catastrophes tend to occupy suboptimal habitats or occupy the remaining fragments (Melles et al. 2003). These fragments are able to sustain only a small fraction of the original avifauna, while at the same time these fragments are often colonized by new species, better adapted to disturbed or early successional environments (Yahner 1998; Donnelly and Marzluff 2004; Sánchez et al. 2004). Colonization may slow the number of species lost (Harris 1984; Lovejoy et al. 1984; Bierregaard and Dale 1996; Marzluff 2005).

The conservation importance of remnants embedded in urban areas is well documented in developed countries (Tilghman 1987; Clergeau et al. 1998; Rottenborn 1999; Crooks et al. 2004; Donnelly and Marzluff 2004; Chace and Walsh 2006). However, little is known about the importance of urban fragments and the effect of urbanization on birds in neotropical countries (Fonaroff 1974; Marzluff et al. 2001; Manhães and Loures-Ribeiro 2005; Chace and Walsh 2006; Pauchard et al. 2006).

In Costa Rica the human population growth, its concentration in urban areas, and complete lack of nature-friendly urban-development schemes have resulted in intense deforestation and uncontrolled growth of urban areas (Joyce 2006). Consequently, most bird habitats, such as forest fragments, shade coffee plantations, and corridors along rivers and streams, which until recently covered a relatively large extension around the urban centers in this country have been nearly completely eliminated (Sánchez-Azofeifa et al. 2001). The Costa Rican Central Valley concentrates nearly $2 / 3$ of the Costa Rican population (Fournier 1991, Joyce 2006) and consequently the rich vegetation that formerly covered this valley has been rapidly converted in urban landscapes (Fournier 1991). The remaining forest fragments of different successional stages in the Costa Rican Central Valley have served as habitat to a rich resident avifauna and as important stopover locations for a large number of terrestrial migrants, primarily during autumn migration (Stiles 1990; Naoki et al. 2003). However, these fragments are rapidly disappearing as land transformation continues (Joyce 2006).

It is unusual to have sufficient data to make historical comparisons of the effect of urbanization on reduction of resident birds in a particular area. However Stiles (1990) studied the avifauna of the Universidad de Costa Rica campus for 21 years
(1968-1989). Since then, urban expansion has engulfed the Stiles' study area, which has also been drastically transformed with new buildings and elimination of second growth and forest tracts. The information published by Stiles (1990) offers an opportunity to evaluate the effect of urbanization on resident and migratory birds present in the northeastern section of the Central Valley in Costa Rica. More specifically our objective is to quantify the expansion of the urban landscape between 1973 and 2006 and its effect on bird species richness and relative abundance in a tropical landscape.

\section{Methods}

Study area and bird survey

We conducted this study in an 186 ha urban area on the northeastern section of the Costa Rican Central Valley that includes the campus of the Universidad de Costa Rica, San José province, Costa Rica ( $9^{\circ} 54^{\prime} \mathrm{N}, 84^{\circ} 03^{\prime} \mathrm{W}$; elevation $1200 \mathrm{~m}$ a.s.l.; Fig. 1). Large tracts of premontane forest covered the study area and connected it with the continuous forest of the Central Volcanic mountain range approximately 50-40 years ago (Joyce 2006). Today the original native vegetation is scarce and restricted to small fragments of secondary growth, isolated trees, and gardens (Figs. 1 and 2). F. Gary Stiles mist-netted and sampled birds walking along transects from 1968 to 1989 in this 186 ha area and published his data in 1990 (Stiles 1990).

We sampled birds by walking at a steady pace along four 1-km long transects from 06:00 to 07:30 am every 2 weeks, from March 2004 to May 2005. Transects were set at the same locations Stiles (1990) used to mist net and sample birds: two transects were set at the northeastern limit of the campus (NEC), one at the eastern limit (EC), and one at the central campus (CC). NEC and EC were covered with young secondary forest and small areas of tall grass until 1991. At present $80 \%$ of the area in NEC and nearly $100 \%$ in EC have been cleared; at CC vegetation cover has undergone little change. During each survey we counted all birds seen or heard along each transect. From 2002 through 2005 we additionally conducted bird surveys every 2 weeks from August through December at different locations within and 
Fig. 1 Study area showing the transects used by Stiles (1990) and in this study to sample birds. Some transects include part of other areas outside the study area. At the right upper corner the Costa Rican map indicating the location of the Central Valley

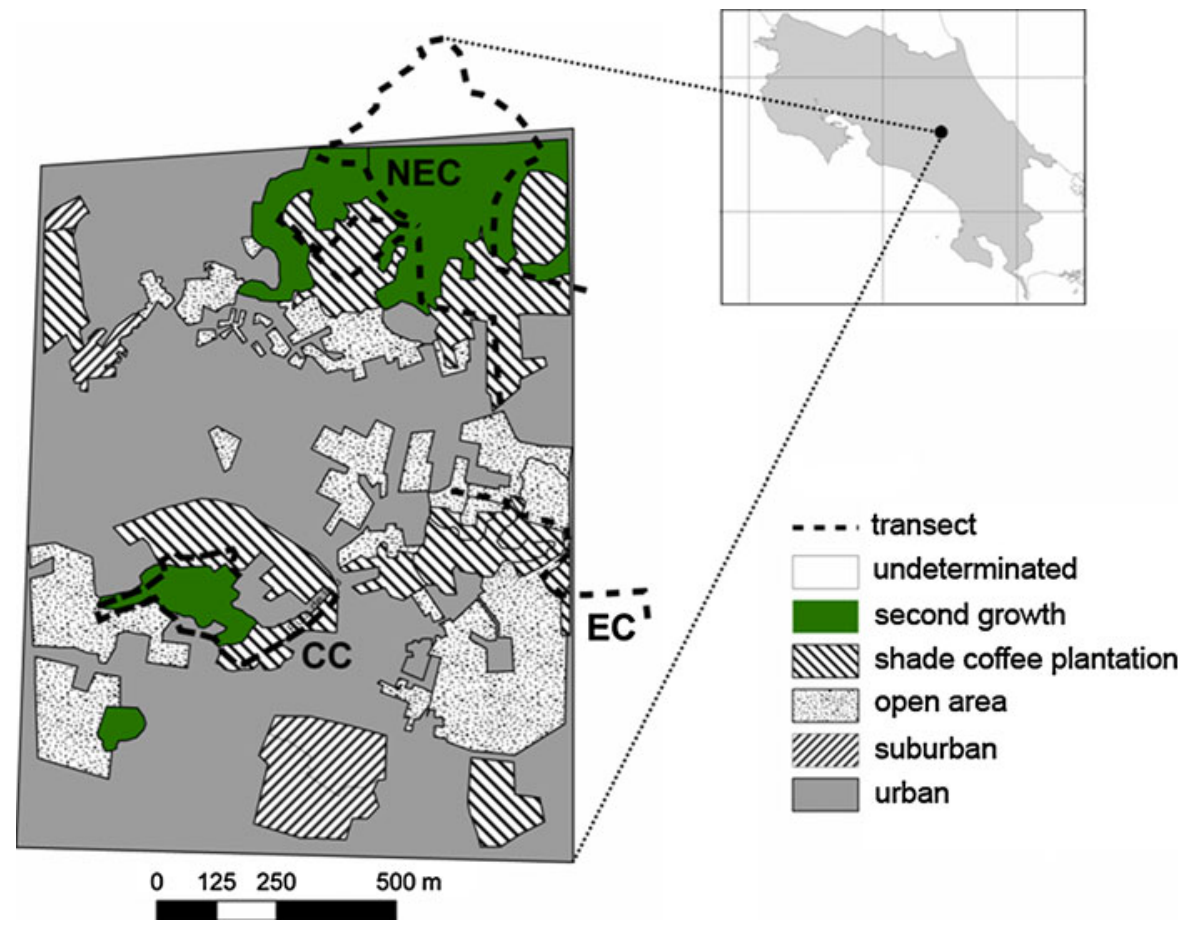

around the campus to complement information on observed species richness. All birds were classified according to residency: resident, if a species was present year round during either Stiles' (1990) or our surveys in the study area; altitudinal migrant, if a Costa Rican resident species had seasonal movements along mountain slopes; northern latitudinal migrant, if the species breeds in North America and was present only during the North American winter; and southern latitudinal migrant, if the species breeds (or used to) in the study area and then migrates to South America. In addition, we mist-netted birds during four seasons (March-June: 2003, 2005, 2006-2007) in the two largest second growth patches $(<1$ ha each one) available in the study area. The few species mist-netted $(n=8)$ were all sampled in transects, thus data from mist-nets were not included in the analyses.

Stiles (1990) did not provide quantitative data for species abundance, he instead provided a categorical measure of abundance for each of the species in his study. Hence, to compare species relative abundance with Stiles' (1990) work, we first averaged the number of individuals of a given species from all samples combined (from March 2004 to May 2005) and divided this value by the number of samples, then classified species into abundance categories following Stiles (1985): rare (less than 1 individual/survey), scarce (1-3 individual/survey), uncommon (3.1-5 individuals/survey), common (5.1-10 individual/survey) and abundant (more than 10 individuals/survey). For migratory species we calculated the abundance categories for the period they were present in the study area. We conducted an overall Sign Test to compare changes in abundance categories between both data sets. Sign test is appropriate to measure the direction of changes of same items (e.g., category of species abundance) between two time periods (e.g., sampling periods; Sokal and Rohlf 1995). We calculated differences in species composition between Stiles' and our samples using Jaccard's similarity index (Magurrran 1988).

We additionally categorized bird species according to their forest dependence (Stiles 1985) and modifications included by Sandoval and Barrantes (2009): $1=$ species that inhabit nearly exclusively mature forest, $2=$ species that occur in areas with at least $50 \%$ of forest cover, and $3=$ species that inhabit open areas. Species that Stiles (1985) scored as 1-2 and 2-3 were re-classified them as 1.5 and 2.5 respectively. Species dependent on wetlands such as streams, ponds, or shores received a score of 4 ; this category 


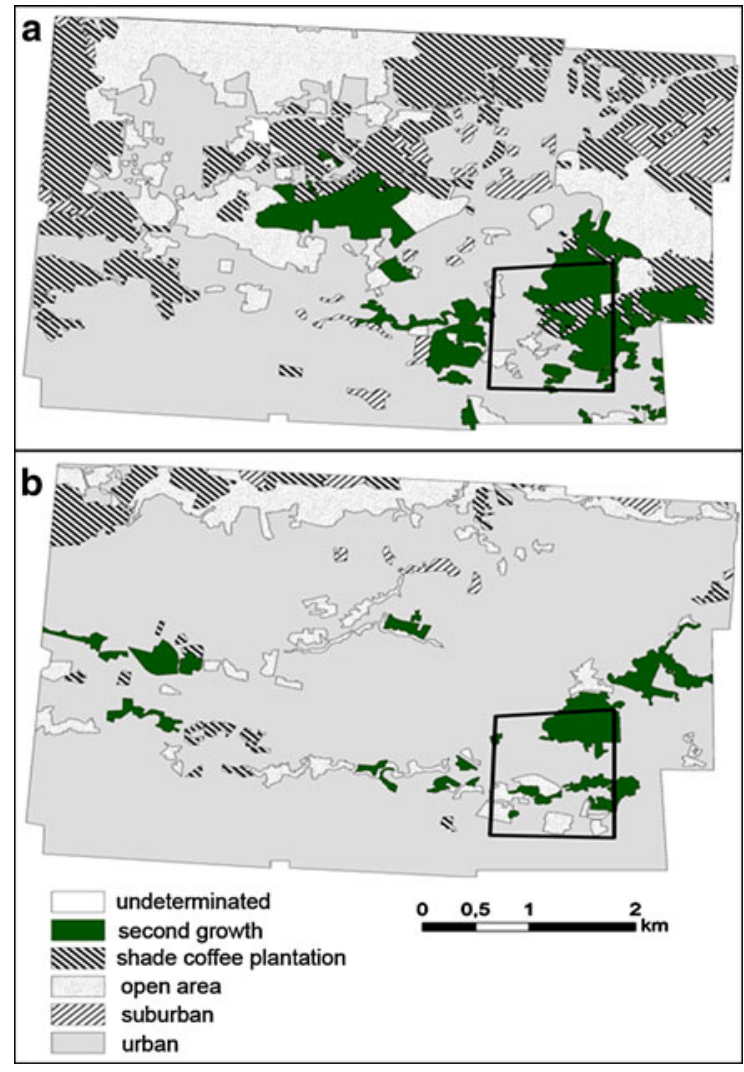

Fig. 2 Area covered by five different habitats in an urban landscape in two time periods (a 1973, b 2006). The landscape area includes the entire area and the study area is enclosed into the polygon near the lower right corner

was not used by Stiles (1985). We compared the relative distribution of observed species richness within each forest and wetland dependence category between both time periods (1989 vs. 2005), using Chisquare tests (Sokal and Rohlf 1995). Species composition was also compared within bird families with 10 or more species between both periods using Sign Tests (Sokal and Rohlf 1995). Since the Sign Test omits those species that are present in both periods when testing the hypothesis that the proportion of species that either disappeared or appeared between periods is similar (Sokal and Rohlf 1995), if a significant difference is revealed, this difference in due to either increase or decrease species richness between both periods. For these analyses Falconidae and Accipitridae were combined within Falconiformes, and Thraupidae, Emberizidae, Cardinalidae, INCERTAE SEDIS (species with unknown family), and Fringillidae were also combined due in part to the recent taxonomic changes and species reorganization within these families (Banks et al. 2003, Chesser et al. 2009). Given that Stiles (1990) surveyed birds for a longer period of time he may have recorded more species due to higher effort and chance alone. However, as Stiles (1990) did not present data on species abundance, it is not possible to correct number of species based on different sample size (e.g., rarefaction). We compared the same bird groups in the Monterverde region using data recorded during 15 years Christmas counts; data were obtained from Christmas Bird Count (CBC) database (National Audubon Society 2010). To evaluate possible changes in number of species within a particular group in the Monteverde region, we compared presence/absence data between the first 3 years (1995-1997) and the last 3 years of the data available (2007-2009) using Wilcoxon Sign Test (Sokal and Rohlf 1995). If a species was present in a given year it received a score of 1 ( 0 if it was absent) and these scores were added for the 3 years and compared between periods, so that a given species could have a maximum score of 3 and a minimum of 0 for a 3 -year period. For all Sign Test analyses we report the number of species in the first $\left(N_{1}\right)$ and second $\left(N_{2}\right)$ period. To compare changes in relative abundance we averaged the abundance for each 3-year period (1995-1997 and 2007-2009) for each species and compared them for total, resident, and migratory species using Paired- $t$ tests. The software PAST 2.02 (Hammer et al. 2001) was used for all statistical analyses.

\section{Landscape analysis}

To measure changes in land use, we analyzed aerial images from three different periods; 1973, 1990, and 2006. Images of 1973 and 1990 were obtained from airplane aerial photos from the Instituto Geográfico Nacional de Costa Rica (IGNCR) and images from 2006 were obtained from Google Earth 2008. All images were georeferenced to Lambert North georeferencing system with reference Abra (IGNCR 1973) cartographic sheet digitalized. We re-scaled and digitalized land cover layers by year at a scale of 1:5000 (including aerial photos and Google Earth images), and then we classified them into five categories, based on visual interpretation: urban, suburban, second growth, shade coffee plantations, and open areas. Urban category includes buildings, 
houses, and streets; suburban includes gardens, parks, and small edifications scattered within large parks and gardens; second growth includes patches of secondary forest in different successional stages; shade coffee plantations includes mainly shade coffee plantations and tree windbreaks; and open areas includes pastures and other crop fields. Field-based accuracy assessments for classifications of historical photographs is not possible, but for the 2006 image we compared the structure of the landscape observed in the images with field data prior assigning the different categories. To reduce likelihood of misclassification and make comparisons across periods possible we combined pastures and small crop fields (e.g., tomato, pepper, bean, and corn fields) which were difficult to distinguish in the images to obtain sharply contrasting landscape elements. The confidence on the accuracy of our visual interpretation is also supported by the field research on habitat use of the local avifauna that we have conducted since 1986 in the area.

We measured changes of land use among 1973, 1990, and 2006 in the 186-ha study area (Fig. 1). To have a larger scale approach we also included in the analysis an area of 2886 ha that includes the study area (landscape area hereafter). Changes in this larger area were analyzed between 1973 and 2006, since aerial images were not available for 1990. We measured changes in patches of open areas, shade coffee plantations, second growth, suburban, and urban landscapes between 1973 and 2006 on layers generated from aerial images using the following metrics: (a) area class (ha), (b) number of patches, (c) mean patch size (ha), (d) patch size coefficient of variation, (e) patch size standard deviation (ha). All parameters were calculated using ArcView GIS 3.2 $2^{\mathrm{TM}}$ and the Patch Analyst 3.1 extension (Rempel and Carr 2003).

\section{Results}

Changes in land use

Land use in the study area (186 ha) changed dramatically from 1973 to 2006. Shade coffee plantation and urban terrain showed the largest changes. Shade coffee plantations nearly doubled its area between 1973 and 1990, and changed from a nearly continuous plantation to 13 smaller patches during the same period, which mostly disappeared by 2006 (Table 1, Fig. 2). Second growth area was reduced between 1973 and 1990 when $75 \%$ of the 65 ha that covered this vegetation type was eliminated (Table 1 ). This vegetation recovered part of its original area between 1990 and 2006, so that the lost between 1973 and 2006 was 41\% (Table 1, Figs. 2 and 3). Area covered by open and suburban areas also increased between 1973 and 2006. Suburban habitat increased slowly from 1973, while open area quickly expanded between 1973 and 1990 with little change between this period and 2006 (Table 1, Figs. 2 and 3). As expected, the area covered by urban land increased from 77 to 106 ha between 1973 and 2006 (37\%), but the rate of expansion was similar in both periods: 12.3 ha between 1973 and 1990 and 16 ha more between 1990 and 2006 (Table 1, Figs. 2 and 3).

Similar change in land use occurred at landscape scale. Shade coffee plantations and second growth drastically decreased between 1973 and 2006, but contrary to the study area, suburban and open area also decreased during the same period at this scale (Table 2). A total area of 996 ha (out of the 2886 ha analyzed) was converted into urban terrain between 1973 and 2006 with the consequent reduction of other land covers (Table 2, Fig. 2).

Changes in bird species composition and abundance

We recorded 143 bird species during our study (Electronic supplementary material), while Stiles (1990) reported 188 species for the same area 16 years earlier; for a combined total of 207 species (several species were present in both periods). We did not find 66 species reported by Stiles (1990), but we registered 18 new species (Electronic supplementary material). The similarity between both periods was $58 \%$.

Of the 66 species that disappeared from the area 32 were native resident species, and the other 34 were latitudinal migrants: 30 of these were terrestrial migrants and 4 were wetland-dependent species. When species were compared by their forest dependence (including residents and migrants), we found that observed richness in all categories decreased in similar proportion $\left(\chi^{2}=8.36\right.$, df $=4, P=0.08$ ), but non-forest dependent species had the largest change between both periods (Fig. 4). We recorded seven new non-forest dependent species, but 28 non-forest 
Table 1 Change in area metrics, patch density, patch size, variability metrics, for shage coffee plantations, second growth, open areas, suburban, and urban landuse between 1973, 1990 and 2006 for the study area

\begin{tabular}{|c|c|c|c|c|c|c|c|c|c|c|c|c|c|c|c|}
\hline & \multicolumn{3}{|c|}{$\begin{array}{l}\text { Shade coffee } \\
\text { plantations }\end{array}$} & \multicolumn{3}{|c|}{ Second growth } & \multicolumn{3}{|c|}{ Open areas } & \multicolumn{3}{|c|}{ Suburban } & \multicolumn{3}{|l|}{ Urban } \\
\hline & 1973 & 1990 & 2006 & 1973 & 1990 & 2006 & 1973 & 1990 & 2006 & 1973 & 1990 & 2006 & 1973 & 1990 & 2006 \\
\hline Class area (ha) & 13.60 & 25.45 & 0 & 65.25 & 16.45 & 27.95 & 11.45 & 29.08 & 23.52 & 0 & 6.97 & 10.43 & 77.74 & 90.09 & 106.14 \\
\hline No. of patches & 1 & 13 & 0 & 8 & 5 & 12 & 6 & 24 & 8 & 0 & 4 & 3 & 1 & 3 & 1 \\
\hline $\begin{array}{l}\text { Mean patch Size } \\
\text { (ha) }\end{array}$ & 13.60 & 1.96 & 0 & 8.16 & 3.29 & 2.32 & 1.91 & 1.21 & 2.94 & 0 & 1.74 & 3.48 & 77.74 & 30.03 & 106.14 \\
\hline Patch size CV (ha) & 0.00 & 75.64 & 0 & 134.86 & 56.76 & 102.53 & 62.22 & 151.61 & 58.58 & 0 & 63.90 & 34.59 & 0.00 & 138.93 & 0.00 \\
\hline Patch Size SD (ha) & 0.00 & 1.48 & 0 & 11.00 & 1.87 & 2.39 & 1.19 & 1.84 & 1.72 & 0 & 1.11 & 1.20 & 0.00 & 41.72 & 0.00 \\
\hline
\end{tabular}

$C V$ coefficient variation, $S D$ standard deviation

Fig. 3 Change in area covered by five different habitats in three time periods (1973 white bars, 1990 dashed bars, 2006 black bars) in the study area of (186 ha) in the Central Valley, Costa Rica

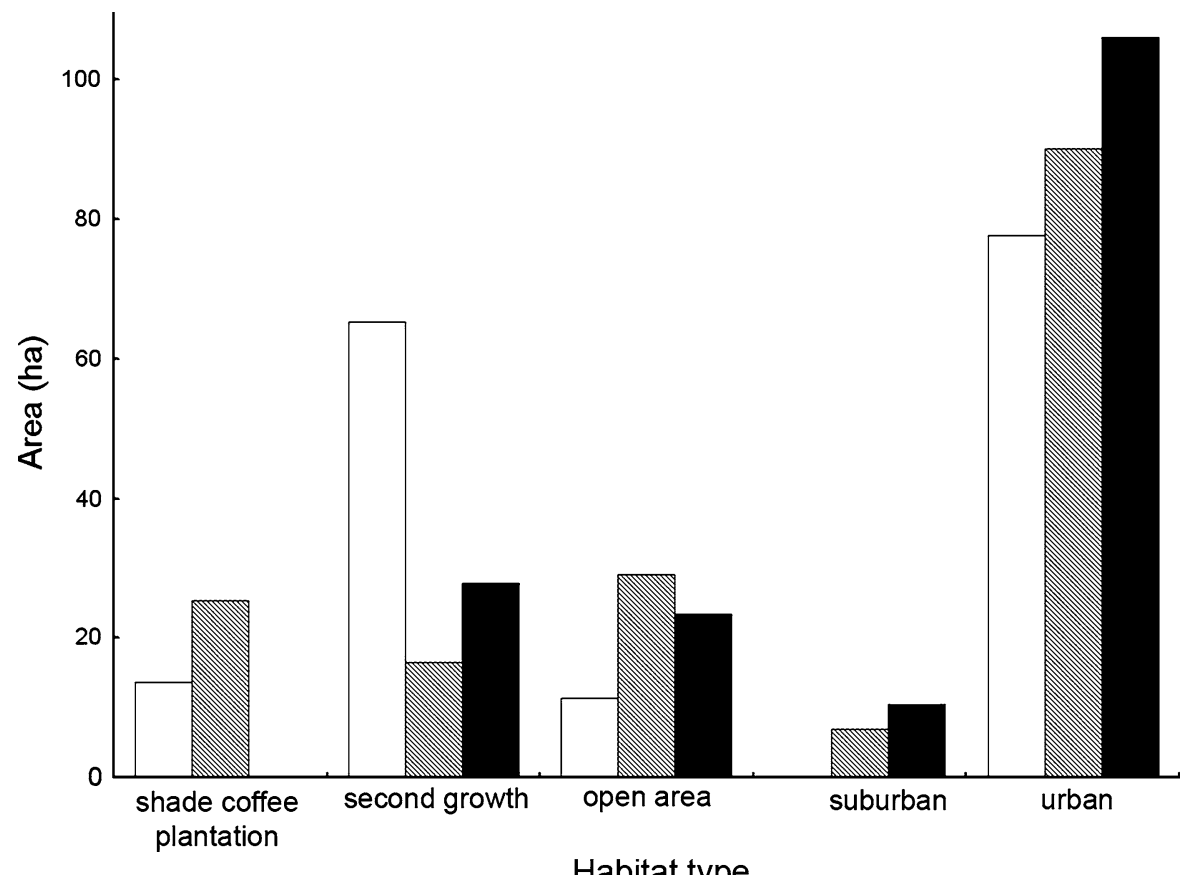

Habitat type dependent species recorded by Stiles (1990) were not registered in the area (Electronic supplementary material). Two other newly recorded species were latitudinal migrants and two were wetland dependent (Electronic supplementary material). The only new forest-dependent species recorded was the Short-tailed Hawk (Buteo brachyurus). Although Stiles (1985) considered this hawk a forest dependent species, it has adapted relatively well to disturbed environments. Wetland species richness also decreased between both periods (Sign test, $P=0.11, N_{1}=12, N_{2}=6$ ), though reduction was not significant.
Changes where not equal across taxonomic groups. Observed species richness (resident and migrants combined) decreased for hummingbirds (Trochilidae; Sign test: $P=0.016, N_{1}=12, N_{2}=5$ ) and warblers (Parulidae; Sign test: $P<0.001, N_{1}=34, N_{2}=20$ ) between 1989 and 2005. Observed species richness for the group that included Thraupidae, Emberizidae, Cardinalidae, INCERTAE SEDIS, and Fringillidae (Sign test: $P=0.34, \quad N_{1}=23, \quad N_{2}=19$ ), flycatchers (Sign test: $P=1, N_{1}=22, N_{2}=22$ ), Falconiformes (Sign test: $P=1, N_{1}=9, N_{2}=8$ ) and icterids (Sign test: $P=0.5, N_{1}=7, N_{2}=9$ ) was similar between 
Table 2 Change in area metrics, patch density, patch size, variability metrics, edge metrics and shape metrics for groves, second growth, and urban landuse between 1973 and 2008 for the landscape area

\begin{tabular}{|c|c|c|c|c|c|c|c|c|c|c|}
\hline & \multicolumn{2}{|c|}{ Shade coffee plantation } & \multicolumn{2}{|c|}{ Second Growth } & \multicolumn{2}{|c|}{ Open areas } & \multicolumn{2}{|c|}{ Suburban } & \multicolumn{2}{|l|}{ Urban } \\
\hline & 1973 & 2006 & 1973 & 2006 & 1973 & 2006 & 1973 & 2006 & 1973 & 2006 \\
\hline Class Area (ha) & 590.70 & 101.49 & 249.81 & 124.57 & 543.94 & 266.30 & 121.28 & 24.39 & 1373.45 & 2369.36 \\
\hline No. of patches & 40.00 & 23.00 & 23.00 & 20.00 & 49.00 & 43.00 & 24.00 & 14.00 & 1.00 & 1.00 \\
\hline Mean patch size (ha) & 14.77 & 4.41 & 10.86 & 6.23 & 11.10 & 6.19 & 5.05 & 1.74 & 1373.45 & 2369.36 \\
\hline Patch Size CV (ha) & 179.39 & 157.15 & 171.61 & 136.83 & 314.79 & 246.96 & 237.06 & 110.40 & 0.00 & 0.00 \\
\hline Patch Size SD (ha) & 26.49 & 6.93 & 18.64 & 8.52 & 34.94 & 15.29 & 11.98 & 1.92 & 0.00 & 0.00 \\
\hline
\end{tabular}

$C V$ coefficient variation, $S D$ standard deviation

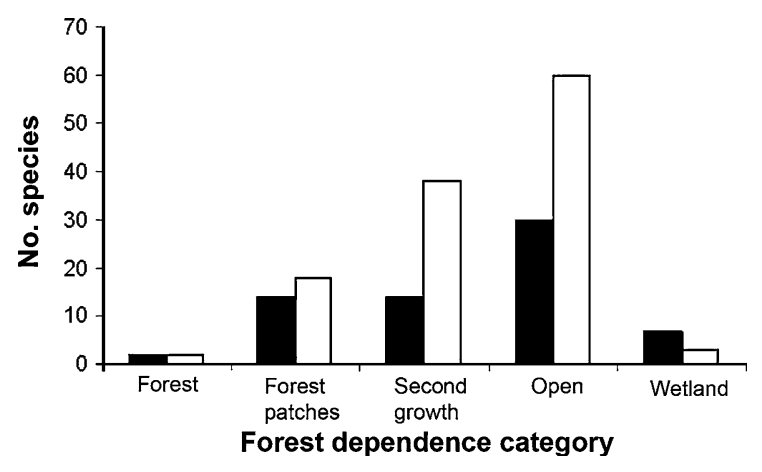

Fig. 4 Number of species by forest dependence category (Forest species highly dependent on forest, and those that require at least $50 \%$ of forest cover, Forest patches species that require at least small forest patches; Second growth species require at least bushy vegetation; Open species that inhabit open areas; Wetland species require some aquatic habitat). Black bars indicate species recorded by Stiles (1990) but absent in this study; white bars are species present in both studies. New recorded species are not included

both periods (Electronic supplementary material). Within resident species, observed richness drastically decreased for altitudinal migrants (Sign test: $P=0.015$, $N_{1}=10, N_{2}=3$ ) and hummingbirds (Sign test: $\left.P=0.016, N_{1}=12, N_{2}=5\right)$ between both periods. For the group that included resident Thraupidae, Emberizidae, Cardinalidae, INCERTAE SEDIS, and Fringillidae (Sign test: $P=0.11, N_{1}=16, N_{2}=14$ ) and for resident flycatchers (Sign test: $P=0.81$, $N_{1}=10, N_{2}=10$ ) no significant change in observed species richness was detected. For the Monteverde area we did not detect significant changes in observed species richness for any of the same birds analyzed on the Universidad de Costa Rica campus (Table 3).

In general, relative abundance decreased for the 122 species (resident and migrants combined) present in both periods (1989 and 2005, when relative abundance was estimated) (Sign test: $P<0.001$, $N_{1}=188, N_{2}=141$ ). Of these 122 species, the relative abundance decreased for 76 species between both periods, increased for 12, and was similar for 34 species. The relative abundance of most resident species significantly decreased over the 16 year period (Sign test: $P<0.001, N_{1}=98, N_{2}=84$ ). The relative abundance decreased for 34 species, increased for 11 species and remained the same for 25 species of the 70 resident species present in both periods. Similarly, the relative abundance decreased for migratory species (Sign test: $P<0.001, N_{1}=90, N_{2}=57$ ). For the migratory species present in both periods, relative abundance decreased for 42 species, increased for 1 , and was similar for 9 species. For the Monteverde region the relative abundance did not change for the 530 species analyzed (resident and migrants combined; Paired $t$-test $=0.98$, df $=529, \quad P=0.33$ ) between both periods (1994-1996 and 2007-2009). Relative abundance neither change for resident species (Paired $t$-test $=1.17, \mathrm{df}=440, P=0.24$,), but it increased for migratory species between both periods (Paired $t$-test $=-2.23$, df $=88, P=0.03$ ).

\section{Discussion}

The accelerated expansion of the urban landscape in Costa Rica during the last three decades has eliminated a large proportion of natural and semi-natural (e.g., polyculture shade coffee systems) habitats, increased the isolation of the native vegetation used by local and migratory avifauna, and as a result drastically reduced the rich avifauna that until recently was characteristic 
Table 3 Quantitative comparison (Wilcoxon test) of observed species richness between two periods for the Monteverde region, Costa Rica

\begin{tabular}{|c|c|c|c|c|}
\hline Taxa & 1994-1996 & $2006-2009$ & Wilcoxon $(Z)$ & $P$ \\
\hline Falconidae + Accipitridae + Pandionidae & 26 & 26 & -1.60 & 0.11 \\
\hline Trochilidae & 34 & 28 & -1.29 & 0.20 \\
\hline Tyrannidae & 50 & 51 & -0.41 & 0.68 \\
\hline Parulidae & 31 & 33 & -0.25 & 0.80 \\
\hline $\mathrm{T}+\mathrm{E}+\mathrm{C}+\mathrm{IS}+\mathrm{F}$ & 61 & 65 & 0.52 & 0.60 \\
\hline Icteridae & 11 & 9 & -0.34 & 0.73 \\
\hline
\end{tabular}

Data was obtained from Christmas counts. $(\mathrm{T}+\mathrm{E}+\mathrm{C}+\mathrm{IS}+\mathrm{F}$ : Thraupidae, Emberizidae, Cardinalidae, INCERTAE SEDIS, and Fringillidae)

of this region (Slud 1964; Stiles 1990). The rich avifauna in the Central Valley is the result of its topography and convergence of several life zones (Gómez 1986). This valley is surrounded by the Talamanca and Central mountain ranges, mountains that have the highest species richness and highest endemism in Central America (Stiles 1983; Jankowski and Rabenold 2007; Barrantes 2009). Through mountain passes, bird species from the Caribbean region expand their distribution into this valley, forming a rich mosaic composed of birds from several biogeographic regions (Naoki et al. 2003). In addition, the Central Valley apparently has served as an important stopover area, chiefly during autumn migration, for terrestrial migrants that annually move between North America and neotropical wintering regions (Stiles 1990; Naoki et al. 2003). This biologically diverse area is severely threatened by urbanization.

Urbanization has dramatically reduced observed species richness and abundance of the resident and migratory avifauna but not all groups have been equally affected. Within residents, few forest dependent species experienced local extinction (Electronic supplementary material). This result is expected since natural habitats had already been drastically altered in the Central Valley by the early 1970's (Sader and Joyce 1988; Fournier 1991). During the period Stiles (1990) conducted his investigation forest tracts consisted of mainly secondary growth forests (Fournier 1991) and many forest dependent species were already absent (Electronic supplementary material). On the contrary a large number of non-forest dependant species were likely extirpated, mostly by elimination of large tracts of second growth vegetation of diverse age and structural complexity. Nearly all species that have apparently been extirpated from the study area since 1990 were already reported as scarce or rare by Stiles (1990; Electronic supplementary material), indicating that rarity predicts local extinction in urban landscapes as it does for more natural habitats (Kattan 1992; Goerck 1997). An exception to this pattern is the Common Ground-Dove (Columbina passerina) which was a common species until the late 1990's (GB pers. obs.). Disappearance of this species from the study area is difficult to explain since it was apparently well adapted to gardens and other open areas.

Although ecological or taxonomic groups may be affected as a whole, species-specific responses to urbanization are also expected. For instance, seven of the 12 hummingbird species present in 1989 disappeared by 2005 (Electronic supplementary material). Most of these species were altitudinal migrants (Stiles 1983) and their disappearance was likely caused by reduction in forest connectivity and reduction in food resources (e.g., flower patches). Similarly, other species such as the Steely-vented Hummingbird (Amazilia saucerrottei) that maintained a high breeding population in the study area also disappeared over the years, suggesting a gradual reduction in resources, and likely higher competition as available habitats decreased and isolation increased. In contrast, Rufoustailed Hummingbird (A. tzacatl), still maintains a breeding population but its relative abundance has decreased in recent years. This indicates that some species are more resilient to habitat alteration than others, even within the same ecological or taxonomic group. Species with specialized life history traits, habitat requirements, or reduced behavioral plasticity are expected to disappear first when urbanization expands (O'Dea and Whittaker 2007). This appears to 
be the case for altitudinal migrants, which are species that required continuous and/or relatively large tracts of dense forest throughout their movement range (Stiles 1988; Loiselle and Blake 1991; Chaves-Campos 2004). For instance, Flame-colored Tanager (Piranga bidentata), Mountain Elaenia (Elaenia frantzii), Mountain Robin (Turdus plebejus) were regular visitors at the study area during their altitudinal movements. From all altitudinal migrants $(N=10)$ only Mountain Elaenia (1 individual in 5 years) and Elegant Euphonia (Euphonia elegantissima) (2 individuals in 4 years) are occasionally seen.

Some non-forest dependent species are apparently specialized to particular successional vegetation stages (Barrantes and Sandoval, unpublished data), and if such areas disappear or decline, relative abundance of birds associated with these vegetation types are drastically reduced or may even be lost from the area. This is apparently the case of nightjars (e.g., Chordeiles acutipennis and Nyctidromus albicollis) and some owls (e.g., Megascops choliba and Pseudoscops clamator) that naturally occupy forest edges, large forest gaps, and dense thickets (Stiles and Skutch 1989) and now have very low densities or are absent in the study area. Swifts are another group of birds with drastically reduced abundance in the study area. Swifts breed behind waterfalls of pristine streams and their reduction is likely related with destruction of nesting places nearby the study area (Marín and Stiles 1992; Marín and Sánchez 1998) and elimination of foraging grounds.

The reduction in observed richness of migratory species was also notable, particularly for warblers (Electronic supplementary material): $64 \%$ of the species registered by 1990 (Stiles 1990) have not been registered during at least the last 10 years. Most of these species (e.g., Vermivora chrysoptera, V. cyanoptera, and Dendroica cerulea) are seriously threatened as many have experienced extensive destruction of breeding habitats (Wilcove 1985; Johnston and Hagan 1992; Donovan et al. 1995), tropical wintering habitats (Terborgh 1989; Faaborg and Arendt 1992; Rappole and McDonald 1994; Norris et al. 2004), and loss of habitat on stopover sites (Rappole et al. 1993; Hutto 2000; Mehlman et al. 2005; Kirby et al. 2008). Similar to the resident avifauna, migratory species that were registered in both study periods also showed drastic reductions in relative abundance.
Monteverde region is located at the same elevation that our study area and covered chiefly by protected forest (Burlingame 2000), making it an appropriate control area to examine the effect of urban expansion on reduction and local extinction of resident and migratory birds. The reduction in observed species richness and abundance in the study area is a phenomenon most likely caused by urban expansion, since no changes were detected in species richness, and the only change in abundance was in the opposite direction (i.e., relative abundance of migrants increased between periods) for the same bird groups in the Monteverde region over a period of 15 years. The contrasting differences in the pattern of observed species richness and relative abundance between both regions indicate that local extinction may occur at a fast rate as urban sprawls into adjacent more natural habitats. Monteverde region has remained relatively undisturbed for the last five decades (Burlingame 2000), contrasting with the rapid urban sprawl in the Costa Rican Central Valley.

The new species registered in our study area consist primarily of species originally restricted to tropical dry forests, e.g., Rufous-naped Wren (Campylorhynchus rufinucha), White-winged Dove (Zenaida asiatica), White-fronted Parrot (Amazona albifrons), and invasive species well adapted to open areas, e.g., Variable Seedeater (Sporophila americana), and Melodious Blackbird (Dives dives). Range expansion of tropical dry forest birds is becoming a common phenomenon in Costa Rica. For these species rain forests apparently function as an ecological barrier that limits their expansion (Stotz et al. 1996; Barrantes and Sánchez 2003). Therefore, elimination of large tracts of rain forest allows the expansion of these species which are already adapted to relatively open environments (Electronic supplementary material), given that dry forest is quite open during the dry season when most trees lose their leaves (Hartshorn 1983). After deforestation it is also common that species of open habitats invade and establish in these newly available habitats (Renjifo 1999). Invasion of these species likely increases the extinction rate of the local avifauna as they are better adapted to exploit the resources in highly altered environments (O'Connor 1986).

A few species like the Gray-necked Wood-Rail (Aramides cajanea) that had been rarely observed by Stiles (1990) recently established a small breeding population in and around the study area, occupying 
small tracts of dense secondary forests near streams. This species typically inhabits lower elevations and likely moved through forest corridors along streams and rivers, indicating that at least for some bird species there may still be a certain degree of connectivity (Barrantes and Pereira 2002; Barrantes and Biamonte-Hidalgo 2004).

Urban expansion occurring in Costa Rica is also a common phenomenon in other developing neotropical countries. The elimination of natural habitats, which first has drastically reduced the relative abundance of the birds inhabiting the area will likely cause the local extinction of a large number of species (Graham and Blake 2001; Devictor et al. 2007; Shodi et al. 2008), especially those species with more specialized habitat requirements or life history traits (e.g., altitudinal migrants). Our results also showed that a large number of species maintained breeding populations in small patches of secondary forest and other semi-natural habitats only 16 years ago (Stiles 1990). Most important, these results indicate that with a little effort of our society and a better planned urbanization it is possible to conserve a large portion of our rich biodiversity (Miller and Hobbs 2002).

Acknowledgments We thank all students that help in bird surveys, especially Cesar Sánchez, Vivian Steinford and Roxana Araya. We also kindly thank Bette Loiselle, John Marzluff and two anonymous reviewers for valuable comments that largely improved a previous version of this manuscript. Financial support was provided by the Vicerrectoría de Investigación, Universidad de Costa Rica.

\section{References}

Alig RJ, Healy RG (1987) Urban and build-up land area changes in the U.S.: an empirical investigation of determinants. Land Econ 63:215-226

Banks RC, Cicero C, Dunn JL, Kratter AW, Rasmussen PC, Remsen JV Jr, Rising JD, Stotz DF (2003) Forty-fourth supplement to the American Ornithologists' Union, check-list of North American birds. Auk 120:923-931

Barrantes G (2009) The role of historical and local factors in determining species composition of the highland avifauna of Costa Rica and western Panamá. Rev Biol Trop 57(1): 333-349

Barrantes G, Biamonte-Hidalgo E (2004) Range expansion of Ramphocelus costaricensis (Aves: Thraupidae) to the northeastern Central Valley, Costa Rica. Brenesia 62: 101-102

Barrantes G, Pereira A (2002) Seed dissemination by frugivores birds from forest fragments to adjacent pastures on western slope of Volcán Barva, Costa Rica. Rev Biol Trop 50:569-576

Barrantes G, Sánchez JE (2003) Geographical distribution, ecology, and conservation status of Costa Rican dry forest avifauna. In: Gordon F, Mata A, Vinson SB (eds) Biodiversity conservation in Costa Rica: learning the lesson in a seasonal dry forest. University of California Press, California, pp 147-159

Bierregaard RO, Dale VH (1996) Islands in an ever-changing sea: the ecological and socioeconomic dynamics of Amazonian rainforest fragments. In: Schelhas J, Greenberg R (eds) Forest patches in tropical landscapes. Island press, Washington DC, pp 187-204

Bierregaard RO, Lovejoy TE (1988) Birds in Amazonian forest fragments: effects of insularization. Proc Int Ornith Congr 19:1564-1579

Burlingame LJ (2000) Conservation in the Monteverde zone. In: Nadkarni NM, Wheelwright NT (eds) Monteverde. Ecology and conservation of a tropical cloud forest. Oxford University Press, Oxford, NY, pp 351-375

Chace JF, Walsh JJ (2006) Urban effects on native avifauna: a review. Landsc Urban Plan 74:46-69

Chaves-Campos J (2004) Elevational movements of large frugivorous birds and temporal variation in abundance of fruits along an altitudinal gradient. Ornit Neotrop 15: 433-445

Chesser RT, Banks RC, Barker FK, Cicero C, Dunn JL, Kratter AW, Lovette IJ, Rasmussen PC, Remsen JV Jr, Rising JD, Stotz DF, Winker K (2009) Fiftieth supplement to the American Ornithologists' Union, check-list of North American birds. Auk 126:705-714

Clergeau P, Savard JPL, Mennenchez G, Falardeau G (1998) Bird abundance and diversity along an urban-rural gradient: a comparative study between two cities on different continents. Auk 100:413-425

CR IGN (1973) Hoja cartográfica Abra. Segunda Edición. Escala 1:50.000. San José, Costa Rica

Crooks KR, Suarez AV, Bolger DT (2004) Avian assemblages along a gradient of urbanization in a highly fragmented landscape. Biol Conserv 115:451-462

Devictor V, Julliard R, Couvet D, Lee A, Jiguet F (2007) Functional homogenization effect of urbanization on bird communities. Conserv Biol 21:741-751

Donnelly R, Marzluff JM (2004) Importance of reserve size and landscape context to urban bird conservation. Conserv Biol 18:733-745

Donovan TM, Thompson FR III, Faaborg J, Probst JR (1995) Reproductive success of migratory birds in habitat sources and sinks. Conserv Biol 9:1380-1395

Faaborg J, Arendt SJ (1992) Long-term declines of winter resident warblers in a Puerto Rican dry forest: which species are in trouble? In: Hagan JM, Johnston DW (eds) Ecology and conservation of neotropical migrant landbirds. Smithsonian Institution Press, Washington DC, pp 57-63

Fonaroff LS (1974) Urbanization, birds, and ecological change in Northwestern Trinidad. Biol Conserv 64:258-262

Fournier LA (1991) Desarrollo y perspectiva del movimiento conservacionista costarricense. Editorial Universidad de Costa Rica, San José, Costa Rica 
Goerck JM (1997) Patterns of rarity in the birds of the Atlantic forest of Brazil. Conserv Biol 11:112-118

Gómez LD (1986) Vegetación de Costa Rica. Apuntes para una biogeografía costarricense. Universidad Estatal a Distancia, San José, Costa Rica

Graham CH, Blake JG (2001) Influence of patch- and landscape-level factors on bird assemblages in fragmented tropical landscape. Ecol Appl 11:1709-1721

Hammer $\varnothing$, Harper DAT, Ryan PD (2001) PAST: Paleontological statistics software package for education and data analysis. Palaeontol Electron 4:1-9

Harris LD (1984) The fragmented forest Island biogeography theory and the preservation of biotic diversity. University of Chicago Press, Chicago

Hartshorn GS (1983) Plants. In: Janzen DH (ed) Costa Rican natural history. University of Chicago Press, Chicago, pp 118-157

Harvey CA, Komar O, Chazdon R, Ferguson BG, Finegan B, Griffith DM, Martínez-Ramos M, Morales H, Nigh R, Soto-Pinto L, van Breugel M, Wishnie M (2008) Integrating agricultural landscapes with biodiversity conservation in the Mesoamerican hotspot. Conserv Biol 22:8-15

Hughes J, Daily GC, Ehrlich PR (1997) Population diversity: its extent and extinction. Science 278:689-692

Hutto RL (2000) On the importance of en route periods to the conservation of migratory landbirds. Stud Avian Biol 20:109-114

Jankowski JE, Rabenold KN (2007) Endemism and local rarity in birds of neotropical montane rain forest. Biol Conserv 138:453-463

Johnston DW, Hagan JM III (1992) An analysis of long-term breeding bird censuses from eastern deciduous forests. In: Hagan JM, Johnston DW (eds) Ecology and conservation of neotropical migrant landbirds. Smithsonian Institution Press, Washington DC, pp 75-84

Joyce AT (2006) Land use change in Costa Rica: 1996-2006, as influenced by social, economic, political, and environmental factors. Litografía e imprenta LIL, S.A., San José, Costa Rica

Kattan GH (1992) Rarity and vulnerability - the birds of the Cordillera Central of Colombia. Conserv Biol 6:64-70

Kirby FS, Stattersfield AJ, Butchart SHM, Evans MI, Grimmett RFA, Jones VR, O'Sullivan J, Tucker GM, Newton I (2008) Key conservation issues for migratory land- and waterbird species on the world's major flyways. Bird Conserv Intern 18:S49-S73

Loiselle BA, Blake JG (1991) Temporal variation in birds and fruits along an elevational gradient in Costa Rica. Ecology 72:180-193

Lovejoy TE, Rankin JM, Bierregaard RO Jr, Brown KS Jr, Emmons LH, van der Voort ME (1984) Ecosystem decay of Amazon forest remnants. In: Nitecki M (ed) Extinctions. University of Chicago Press, Chicago, pp 295-325

Magurrran AE (1988) Ecological diversity and its measurement. Princeton University Press, Princeton, NJ

Manhães MA, Loures-Ribeiro A (2005) Spatial distribution and diversity of bird community in an urban area of southeast Brazil. Brazilian Arch Biol Technol 48:285-294

Marín M, Sánchez JE (1998) Breeding of the Black Swift (Cypseloides niger) in Costa Rica. Ornitol Neotrop 9:219-221
Marín M, Stiles FG (1992) On the biology of five species of swifts (Apodidae, Cypseloidinae) in Costa Rica. Proc West Found Vertebr Zool 4:287-351

Marzluff JM (2005) Island biogeography for an urbanizing world: how extinction and colonization may determine biological diversity in human-dominated landscapes. Urban Ecosyst 8:157-177

Marzluff JM, Bowman R, Donnelly R (2001) A historical perspective on urban bird research: trends, terms, and approaches. In: Marzluff JM, Bowman R, Donnelly R (eds) Avian ecology and conservation in an urbanizing world. Kluwer Academic Publishers, Norwell, pp 1-17

Mehlman DW, Mabey SE, Ewert DN, Duncan C, Abel B, Cimprich D, Sutter R, Woodfrey M (2005) Conserving stopover sites for forest-dwelling migratory landbirds. Auk 122:1-11

Melles S, Glenn S, Martin K (2003) Urban bird diversity and landscape complexity: species-environment associations along a multiscale habitat gradient. Conserv Ecol 7:5. Available from http://www.consecol.org/vol7/iss1/art5 (accessed November 2009)

Miller JR, Hobbs RJ (2002) Conservation where people live and work. Conserv Biol 16:330-337

Naoki K, Durán F, Sánchez JE (2003) La avifauna de un fragmento de bosque secundario en el Valle Central, Costa Rica: su estacionalidad e implicación para la Conservación. Brenesia 59-60:49-64

National Audubon Society (2010) The christmas bird count historical results [Online]. Available from http://www. audubon.org/bird/cbc. Accessed July 2010

Norris DR, Marra PP, Kyser TK, Sherry TW, Ratcliffe LM (2004) Tropical winter habitat limits reproductive success on the temperate breeding grounds in a migratory bird. Proc R Soc London B 271:59-64

O'Connor RJ (1986) Biological characteristics of invaders among bird species in Britain. Phil Trans R Soc London B 314:583-598

O'Dea N, Whittaker RJ (2007) How resilient are Andean montane forest bird communities to habitat degradation? Biodiv Conserv 16:1131-1159

Pauchard A, Aguayo M, Peña E, Urrutia R (2006) Multiple effects of urbanization on the biodiversity of developing countries: the case of a fast-growing metropolitan area (Concepción, Chile). Biol Conserv 127:272-281

Primack RB (1998) Essentials of conservation biology. Sinauer Associates Inc, Sunderland

Rappole JH, McDonald MV (1994) Cause and effect in population declines of migratory birds. Auk 111:652-660

Rappole JH, Morton ES, Lovejoy TE, Ruos JL (1993) Aves migratorias Nearticas en los Neotropicos. RR Donnelley and Sons Co, Virginia

Rempel RS, Carr AP (2003) Patch Analyst Extension for Arcview, Version 3. Available from http://flash.lakeheadu. ca/ rrempel/patch/index.html. Accessed January 2009

Renjifo LM (1999) Composition changes in a subandean avifauna after long-term forest fragmentation. Conserv Biol 13:1124-1139

Rottenborn SC (1999) Predicting the impacts of urbanization on riparian bird communities. Biol Conserv 88:289-299

Sader SA, Joyce AT (1988) Deforestation rates and tends in Costa Rica-1940 to 1983. Biotropica 20:11-19 
Sánchez JE, Barrantes G, Durán F (2004) Distribución, ecología y conservación de las aves de la cuenca del río Savegre, Costa Rica. Brenesia 61:63-93

Sánchez-Azofeifa GA, Harriss RC, Skole DL (2001) Deforestation in Costa Rica: a quantitative analysis using remote sensing imagery. Biotropica 33:378-384

Sandoval L, Barrantes G (2009) Relationship between species richness of excavator birds and cavity-adopters in seven tropical forests. Wilson J Ornithol 121:75-81

Shodi NS, Posa MRC, Lee TM, Warkentin IG (2008) Effects of disturbance or loss of tropical rainforest on birds. Auk 125:511-519

Slud P (1964) The birds of Costa Rica. Distribution and ecology. Bulletin of the American Museum of Natural History 128:1-430

Sokal RR, Rohlf FJ (1995) Biometry. W.H. Freeman and Company, NY

Stiles FG (1983) Birds. In: Janzen DH (ed) Costa Rican natural history. University of Chicago Press, Chicago, pp 502-530

Stiles FG (1985) Conservation of forest birds of Costa Rica: problems and perspectives. In: Diamond AW, Lovejoy TS (eds) Conservation of tropical forest birds. Technical Publication Number 4. International Council for Bird Preservation, Cambridge, UK, pp 121-138
Stiles FG (1988) Elevational movements of birds on the Caribbean slope of Costa Rica: implications for conservation. In: Almeda F, Pringle CM (eds) Tropical rain forest: diversity and conservation. California Academy of Sciences, San Francisco, pp 243-258

Stiles FG (1990) La avifauna de la Universidad de Costa Rica y sus alrededores a través de veinte años (1968-1989). Rev Biol Trop 38(2B):361-381

Stiles FG, Skutch AF (1989) A guide to the birds of Costa Rica. Cornell University Press, Ithaca

Stotz DF, Fitzpatrick JW, Parker TA II, Moskovits DK (1996) Neotropical birds. Ecology and Conservation. University of Chicago Press, Chicago

Terborgh J (1989) Where have all the birds gone?. Princeton University Press, Princeton

Tilghman NG (1987) Characteristics of urban woodlands affecting breeding bird diversity and abundance. Landsc Urban Plan 4:481-495

Wilcove DS (1985) Nest predation in forest tracts and the decline of migratory songbirds. Ecology 66:1211-1214

Yahner RH (1998) Changes in wildlife communities near edges. Conserv Biol 2:233-339 